\title{
Prothrombin Fragments 1 and 2 Measurement
}

National Cancer Institute

\section{Source}

National Cancer Institute. Prothrombin Fragments 1 and 2 Measurement. NCI

Thesaurus. Code C82034.

The determination of the amount of prothrombin fragments 1 and 2 present in a sample. 